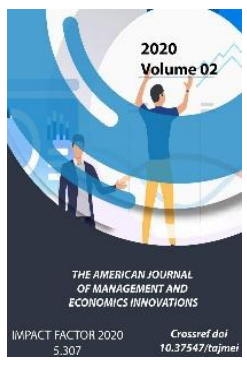

Journal Website: http://usajournalshub.c om/index,php/tajmei

Copyright: Original content from this work may be used under the terms of the creative commons attributes 4.0 licence.

\section{Agrotourism And Its Development's Prospects (On The Example Of Oltinsoy District Of Surkhandarya Region, Uzbekistan)}

Tashpulatov Otajon

Department Of Agro Entrepreneurship Development -Ministry Of Agriculture Of Uzbekistan

Chitose Atsushi

Professor, Tokyo University Of Agriculture And Technology, Japan

Kawabata Yoshiko

Professor, Tokyo University Of Agriculture And Technology, Japan

\title{
ABSTRACT
}

The article highlights the role and importance of tourism in the economy of the Republic of Uzbekistan, as well as the development of agrotourism, the specifics of agrotourism, and its benefits to the tourism industry. The aim of this thesis is identifying the important aspects of introducing the agrotourism among small-scale fermers in Oltinsoy district of Surkhandarya region. The existing agrotourism potential in Oltinsoy district and the directions for further development of agrotourism in the region are also covered by the paper.

\section{KEYWORDS}

Agrotourism, agriculture, tourism, agricultural farm, alternative tourism, mass tourism, rural tourism, income, employment, infrastructure.

DEFINITIONS OF CONCEPTS: Fermer - a farm is an independent economic entity, leading a commodity agricultural production using leased land plots.

Dehkan fermer - dehkan farming is a familysize small-scale farm that produces and sells agricultural products on the basis of the personal labor of family members on the personal plot of land given to the head of the family for a lifetime inheritable possession. 


\section{INTRODUCTION}

Today, tourism is one of the most profitable types of business in the world and it has become an integral part of a market economy and a rapidly developing strategic sector in many countries of the world. Tourism is developing in close cooperation with the world economy's transport, communications, trade, construction, agriculture, and consumer goods industries, and is gaining a significant position in a global economy.

Comprehensive measures are being taken in Uzbekistan to establish tourism as one of the strategic sectors to diversify the national economy, accelerate regional development, create new jobs, increase incomes and living standards of the population and improve investment attractiveness of the country.

The Address of the President of the Republic of Uzbekistan Shavkat Mirziyoyev to the Parliament on January 24, 2020, also states that the transformation of tourism into a strategic sector of the economy remains a priority and includes tasks for the rapid development of the high-potential pilgrimage and medical tourism [1].

The Strategy of Actions for the Further Development of the Republic of Uzbekistan for 2017-2021 also includes directions for the development of the tourism industry, increasing its role and share in the economy, diversification and improving the quality of tourist services, expansion of tourism infrastructure [2].

Over the last few years, the tourism industry in Uzbekistan has been developing rapidly. In 2019, the number of tourists visited Uzbekistan reached 6748.5 thousand, while in 2018 the figure was 5 346.2. World-famous tourist centers such as Samarkand, Bukhara, and Khiva annually attract thousands of foreign tourists to Uzbekistan from all over the world. In 2019, the volume of exports of tourism services reached 1 billion $313 \mathrm{mln}$. dollars USD. All this clearly reflects the scale and results of the state's attention to the development of tourism, which is an integral part of the service sector.

Among the main types of tourism, agrotourism plays an important role. Today, in the professional tourism business, agricultural tourism, as a very profitable type of activity, takes a significant place in the world tourism market. Recently, this type of tourism has been developing in Uzbekistan as well. Agrotourism, as a direction of tourist and recreational activity, is inextricably linked with such concepts as types of tourism as ecological and rural. Many scholars and practitioners disagree on the understanding of these three definitions, and therefore there are several points of view on how rural, agrotourism and ecological tourism relate to each other. The agrotourism in the development of rural life is pivotal. The role of agrotourism in ensuring agricultural development is significant. Because this type of tourism offers the chance to effectively use the opportunities of the region. Also, it provides the development of production and social infrastructure in rural areas and can serve to ensure effective employment for the rural population.

\section{LITERATURE REVIEW}

Agrotourism as a special type of tourism began to develop in the 70s of the twentieth century. In Italy, in 1985 a dedicated law was adopted on the formation and development of agrotourism. The law enshrines the provision of support to farms engaged in agrotourism. For example, conditions were created for them to receive free information, preferential taxation. As a result, the agrotourism industry began to develop rapidly. If in 1985, in the provinces of Italy, farms received about 550 thousand tourists, in 1999 their number increased to 2 million people. Net profit from agrotourism amounted to 350 million US dollars. This gave a tangible impetus to the formation of the independent agrotourism industry and helped 
its development in western Europe Germany, France, and Ireland, and later, in its eastern part - Poland, the Czech Republic, Bulgaria, Ukraine, and Russia (Legge n. 730/1985).

From the terminology point of view, the word "agro" refers to land, land use. It is used in the settlement of land relations. But in practice, it is not. Some researchers (Francois Mouane, 1993) call agrotourism rural, farm or dekhkan tourism, which is not a big mistake. In certain cases, some concepts change their interpretation and content. For example, geography, which was originally understood as the image of the Earth or its surface. In modern understanding, it not only depicts the earth's surface, but also studies complex processes and phenomena of a climatic, hydrological, and geological nature. Many researchers (Tukhliev, Abdullayeva, 2006) divide agrotourism into two components village (kishlak) and farmer. Rural tourism is the introduction of travelers with distant villages, farms, villages, auls. And farm tourism is the location of tourists in the homes of fermers.

Yakubjanova (2016) refers in a narrow sense that's agrotourism is a journey to the objects of the agrarian sector. In a broad interpretation, agrotourism is a journey to purposes of rest, recreation, sports, general educational tasks, familiarization with the processes of agricultural production, implementation products are grown in rural areas.

\section{METHODOLOGY}

Research data's collected from the fermers of Oltinsoy district, tourists who came to Surkhandarya region as a tourist, and tourism agencies which registered in Surkhandarya region.

Only in Oltinsoy district have a higher amount of fermers, even small scale fermers, and horticulture and viticulture fermers than other districts of Surkhandarya region. This was a priority to choose for research.

Methodology is based on questionnaire method.

The questionnaires were disseminated among fermers, tourists and tourism agencies for collecting the data.

In data analyzing part used Chi-Square test and Kruskal-Wallis Test [3].

\section{RESULTS AND DISCUSSION}

Today, the main motives for choosing this type of recreation can be determined as follows: unity with nature; fresh air; organic food; a change of scenery; lack of overcrowding; the need for recovery in these climatic conditions recommended by the doctor; the opportunity to familiarize yourself with another culture and customs; real participation in agricultural work at your own discretion (Lise Lyck and et all, 2012).

World Tourism Organization statistics show that forms of tourism in rural area are increasing. Specialists believe that rural communities will be more successful in the future to carry out agrotourism activities for several reasons [4]:

- In Europe, the aging population leads to an increase in the number of elderly tourists attracted by this form of tourism;

- Rising interest in environmental and health issues;

- Those from urban area have short vacations, so they want destinations that are easy to find and affordable from a financial point of view;

- Increasing number of those who want a quiet tourist area in an unpolluted environment. 
The table below contains the opportunities that agrotourism offers to tourists.

\begin{tabular}{|c|c|}
\hline Element & Features \\
\hline Quiet & $\begin{array}{l}\text { - location away from the noise sources; } \\
\text { - } \quad \text { respect for privacy. }\end{array}$ \\
\hline Healthy food & $\begin{array}{l}\text { - } \quad \text { products obtained in their own household; } \\
\text { - } \quad \text { specific culinary tradition. }\end{array}$ \\
\hline Relax in an active way & $\begin{array}{l}\text { - } \quad \text { climate of relaxation; } \\
\text { - } \quad \text { alternatives to spending leisure time. }\end{array}$ \\
\hline Return to & $\begin{array}{l}\text { - location as close as possible to the } \\
\text { vegetation areas; } \\
\text { - } \text { knowledge of the area's natural resources. }\end{array}$ \\
\hline $\begin{array}{l}\text { Knowledge of the rural } \\
\text { area }\end{array}$ & $\begin{array}{l}\text { - access to traditions, folk costumes, } \\
\text { customs; } \\
\text { - practicing specific rural handicrafts, such } \\
\text { as weaving, pottery, etc.; } \\
\text { - participation at some specific local } \\
\text { holidays. }\end{array}$ \\
\hline Environment refugee & $\begin{array}{l}\text { - location away from the sources of } \\
\text { pollution; } \\
\text { - biologically clean food. }\end{array}$ \\
\hline $\begin{array}{l}\text { Participation in the life } \\
\text { of the rural community }\end{array}$ & $\begin{array}{l}\text { - close proximity between tourist and host; } \\
\text { - discussions on rural issues and how to deal } \\
\text { with them. }\end{array}$ \\
\hline
\end{tabular}

Table 1: Possible elements to offer through agrotourism to potential tourists*

*Source: An author's summary of the scientific literature [11,12,13,14,15]

Uzbekistan has great potential for the formation and development of agrotourism. First, it is an agrarian country, where more than $60 \%$ population live in rural areas. Secondly, the number of farms exceeds 43.7 thousand and they own 889.7 thousand 
hectares of irrigated land. Third, the economic transformation in agriculture has become widespread (Yakubjanova, 2009).

Surkhandarya region is one of the most beautiful regions of Uzbekistan with promising prospects. The tourism potential of the regions is also significant.

Most residents of Surkhandarya are so accustomed to the beauties of their native land, that they are not easily convinced about having a rest not far from home, so more and more they tend to fly away for a week or two to other countries. Today, tourists do not want to live in comfortable luxury hotels, but in a small country house, the simpler the better. Agrotourism attracts mainly residents of the cities who are tired of constant stress, urban traffic jams and restaurant food. Surkhandarya is located in south part of Uzbekistan, share of agriculture in GDP higher than average, Surkhandarya is one of the rural area in Uzbekistan and agricultural developments is relatively in a higher demand than in other regions.

Oltinsoy district has a significant agrotourist potential, which is based on natural, historical, cultural and economic recreational facilities. Irregularity in the placement of various types of agrotourist objects can serve as a basis for determining the priority areas of development of certain types of agrotourist activities in the region.
The following natural prerequisites for the development of agrotourism in the district can be highlighted:

- landscape diversity of the territory;

- heritage of natural beauty of mountains, clean air and waterfalls, etc.;

- a fairly mild climate;

- unique historical objects;

- natural reserve areas of considerable size;

Cultural and historical objects, mainly archaeological (the sites of primitive man of the stone and bronze age, ancient settlements and ancient settlements) and historical are of great value for the development of agrotourism in Oltinsoy.

All these interesting places are located in Oltinsoy, and yet there are still a huge number of routes that will impress even a seasoned tourist.

Primary data collected through questionnaires and interviews and their in-depth analysis have provided more tangible and useful results.

One hundred surveys were carried out among fermers which randomly selected in Oltinsoy district and one hundred interviews filled from the international and local tourists which came to tourism objects of the region.

\begin{tabular}{|c|c|c|c|}
\hline No & Types of activities & $\begin{array}{c}\text { Fermer } \\
(\mathrm{N}=100)\end{array}$ & $\begin{array}{c}\text { Tourist } \\
(\mathrm{N}=100)\end{array}$ \\
\hline 1 & Harvesting & 70 & 10 \\
\hline 2 & Educational tours & 18 & 30 \\
\hline 3 & U-Pick up & 30 & 12 \\
\hline 4 & Preparing processed foods & 64 & 10 \\
\hline 5 & Orchard tours & & 0 \\
\hline
\end{tabular}


Doi: https://doi.org/10.37547/tajmei/Volume02Issue11-03

\begin{tabular}{|c|c|c|c|}
\hline 6 & Hunting and fishing & 1 & 24 \\
\hline 8 & Festival/traditional event & 16 & 36 \\
\hline
\end{tabular}

Table 2: Comparing the agrotourism activities

In order to analyze this data, there is used the Kruskal-Wallis Test. The result was not significant if to look at the table that their willingnesses are mismatching. This is important. Fermers' top proposals are harvesting, orchard tours, U-pick up services. If to start the agrotourism with this type of activities, it is clear there is no success, because tourists don't want to go to these suggestions. They want more diverse type of activities such as educational tours, hunting, fishing, and festivals/traditional events.

So, fermers need to change their minds, they need to be adjusted to tourists desires.

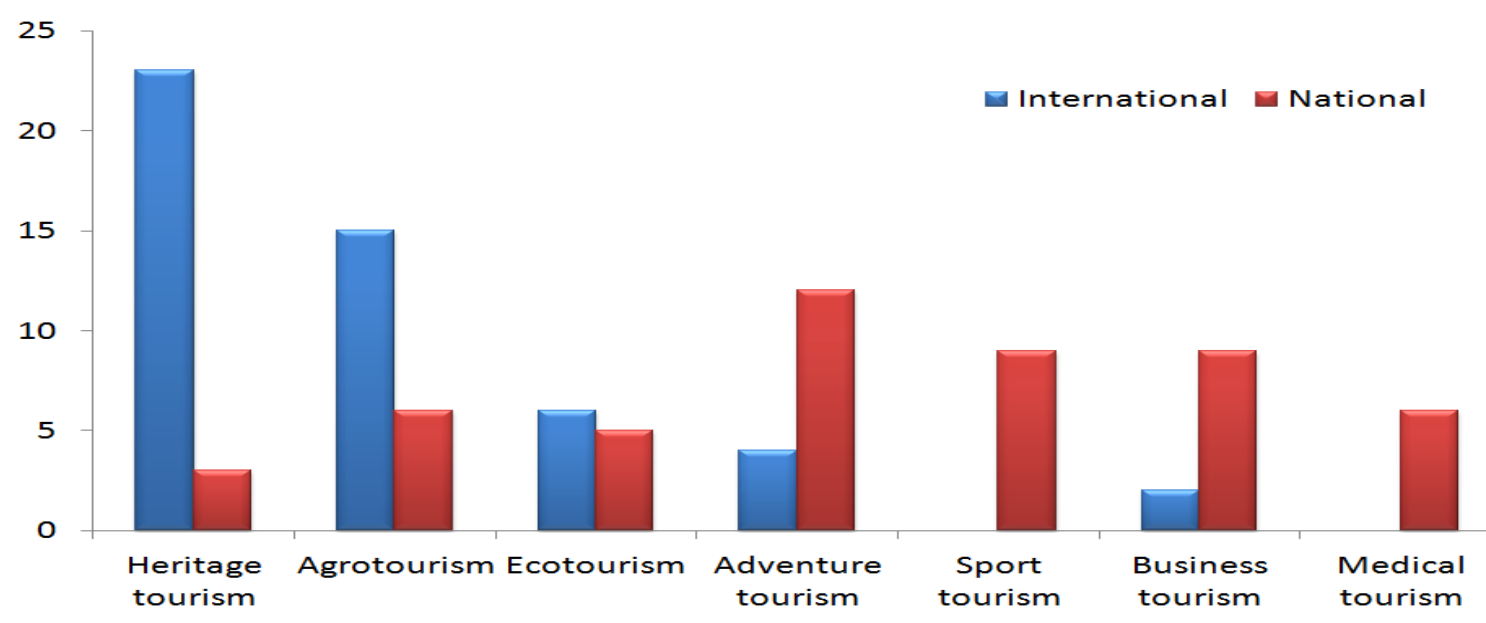

Figure 1. Tourism types of tourists want to go

Figure.1 shows tourists' general proposals to go for tourism compared to other types of tourism. International tourists want more heritage tourism, agrotourism and ecotourism. Results demonstrate that international tourists' demands are higher than national. When setting those up by fermers, they need to consider it. 
The American Journal of Management and Economics Innovations (ISSN - 2693-0811)

Published: November 30, 2020 | Pages: 19-27

Doi: https://doi.org/10.37547/tajmei/Volume02Issue11-03

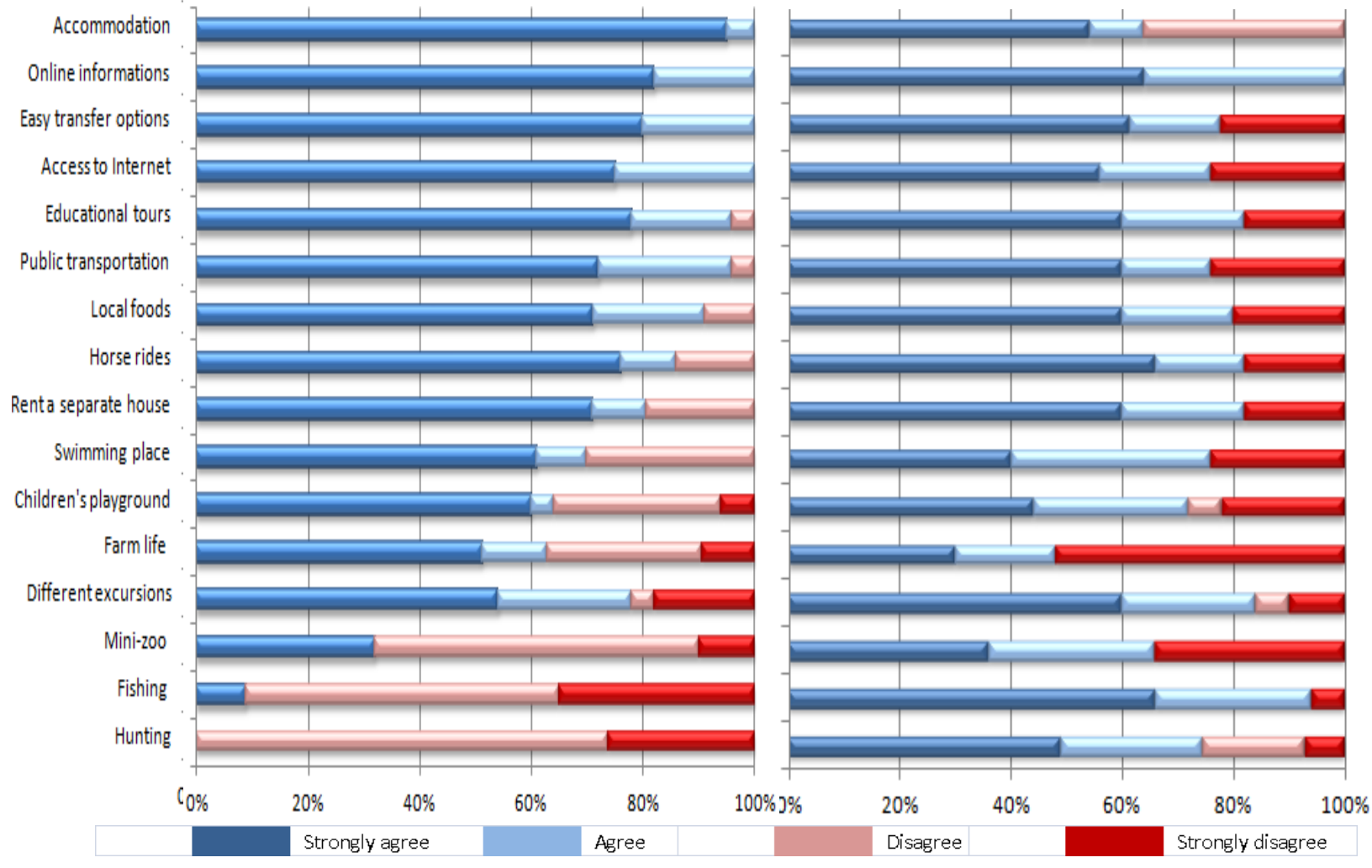

International tourists

National tourists

Figure 2. Comparison of agrotourism factors

This comparison shows the evaluation of agrotourism factors among the international and national tourists. These are also important factors when fermers consider establishing agrotourism. If we take a look at all these 4 factors, these are very important for both national and international tourists. however, international tourists desire is higer than national tourists.

Moreover, hunting and fishing are not interesting for international tourists, but it is highly attractive for national tourists. Above mention factors are crucial for fermers when setting up agrotourism.

In Oltinsoy district there is an enormous potential for agrotourism, but they are not in demand. Therefore, the main task is to explore the agrotourism market and bring information to consumers and help people achieve a common goal - the development of the agricultural sector in Oltinsoy.

\section{CONCLUSION}

The territory of Surkhandarya region runs many diverse tourist routes of mountain, water, pedestrian, bicycle and road. There is limited amount of unique natural resources, but variety amount of rich cultural and historical heritage. Oltinsoy has all necessary conditions for the development of agrotourism. It is a promising recreational district, since it is possible year-round (out-ofseason) maintenance of the holidaymakers. Agrotourism in the district is of particular importance because it combines modern agricultural experience of fermers with unique historical and cultural aspects. The development of agrotourism for this district is highly important. also, Oltinsoy is an area with 
a fairly high agricultural potential, which forms the material basis for agrotourism, and on the other hand, it is a well-known recreational district that allows using this fact as an advertisement in attracting recreants as well as for recreation in the countryside.

Based on the analysis of the Oltinsoy district, there are all opportunities for the development of agrotourism. The nature of these areas and great potential for fermers provides wide range possibilities for the development of this type of tourism. These are territories with traditional, aboriginal, optimal forms of economy that are of great agro-cultural value. In addition, there are historical and natural monuments, the flora and fauna of the district is diverse and unique, which is a prerequisite for the development of agrotourism in this territory.

During the research several important factors were found that are pivotal for the development of agrotourism in Oltinsoy district:

- Fermers' and tourists' interests were mismatching. In order to succeed, fermers have to think more about tourists' desires as They like more festival, traditional events, and educational tours. This is a major potential when starting the agrotourism for fermers;

- There is higher agrotourism interest of organic horticulture and grapes farming management than others;

- Tourism agencies have lack of experience and skills about agrotourism;

- Agrotourism is in high demand among international tourists than national tourists;

- Significant agrotourism is a short term package, among the international tourists;

- Key factors that attract international tourists are housing, online source information, transportation, educational tours, and local foods.
Analysis of the development in the district showed that there were huge resources for agrotourism, but they were not in demand. Therefore, the main task is to explore the market and bring information to consumers and help people achieve a common goal - the development of the agricultural sector not only in Oltinsoy, but also in other districts of Surkhandarya region.

\section{REFERENCES}

1. The Address of the President of the Republic of Uzbekistan, Shavkat Mirziyoyev. January 24, 2020. https://president.uz/uz/lists/view/3324;

2. On the Strategy for the Further Development of the Republic of Uzbekistan, Shavkat Mirziyoyev. February 7, 2017. http://uzsm.uz/en/press_center/ uzb_news/on-the-strategy-for-thefurther-development-of-the-republicof-uzbekistan/;

3. Categories of analysis, https://aaronschlegel.me/;

4. Information from the official website of the World Tourism Organization (UNWTO). UNWTO World Tourism Annual Report 2017;

5. Dubinicheva L.V., Sovetov P.M. Agrotourism in the development of rural areas // Problems of territory development. - 2009. - No. 2 (46). - p. 48-55;

6. Condratov, I. Priorities of Romanian rural tourism. Revista de Turism 2006, 1, p: 48-51.

7. Brezuleanu, S., Brad I. Considerations on agrotourism in the state of BadenWurttemberg, Germany. Works. ST. USAMV Iassi. Agronomy Series. 2001, vol 44;

8. Khamidov O.H. New Stage of Tourism Development in Uzbekistan: Actual Problems and Perspectives. 2017; 
9. Agrotourism: An Educational Tool for the Students with Agro-Food Profile, Ioan Petromana and et all, 2018;

10. Glagoleva L.E. Agritourism - a promising direction of the tourist business in Russia // Economy. Innovation. - 2016. - No. 1 (14) - pp. 4348;

11. Tew, C.; Barbieri, C. The perceived benefits of agritourism: The provider's perspective. Tour. Manag. 2012, 33, 215-224;

12. Bramwell, B. Rural tourism and sustainable rural tourism. J. Sustain. Tour. 1994, 2, 1-6.

13. Ghere, $s, M$. Agroturism, de la Tradi,tie la Oferta Comerciala; Editura Risoprint: Cluj-Napoca, Romania, 2003;

14. Brezuleanu, S.; Brad, I. Considera,tii privind activita,tile agroturistice din landul Baden-Wurttemberg, Germania. Lucr. st. USAMV la,si. Seria Agronomie. 2001, vol. 44.

15. Iorio, M.; Corsale, A. Rural tourism and livelihood strategies in Romania. J. Rural Stud. 2010, 26, 152-162 